

\section{Shirkah}

Journal of Economics and Business

Vol. 2, No. 1, January-April 2017

ISSN: 2503-4235 (p); 2503-4243 (e)

\section{Editor in Chief}

Sri Walyoto

\section{Editorial Boards}

Abu Umar Faruq Ahmad, UBD School of Business and Economics, Brunei Darussalam

Amelia Fauzia,

Asia Research Institute, National University of Singapore, Singapore

Cedomir Nestorovic,

ESSEC Business School Asia Pacific, Singapore

Dwi Condro Triono,

Faculty of Islamic Economics and Business, IAIN Surakarta, Indonesia

Fahmy Radhi,

Faculty of Economics and Business Universitas Gadjah Mada, Yogyakarta,

Indonesia

Hasan Basri,

Syiah Kuala University, Aceh, Indonesia

Johan Fischer,

Department of Social Sciences and Business Roskilde University, Denmark

Masudul Alam Choudhury,

Postgraduate Program in Islamic Economics and Finance, Trisakti University,

Jakarta, Indonesia and the College of Economics and Political Science (CEPS) in

Sultan Qaboos University (SQU), Oman

M. Falik Isbah,

School of Humanities and Social Science, University of New South Wales, Australia M. Ishaq Bhatti,

La Trobe Business School Department of Economics and Finance La Trobe

University, Australia

Najib Kailani,

Pascasarjana, Universitas Islam Negeri (UIN) Sunan Kalijaga, Yogyakarta, Indonesia 
Nunung Nurul Hidayah,

Aston Business School, Aston University, Birmingham, United Kingdom

Shaikh M Ghazanfar,

Departement of Economics, University of Idaho, Russian Federation

\section{Managing Editors}

Fitri Wulandari

Jasanta Perangin-angin

\section{Assistant to Editor}

M. Endy Saputro

M. Zainal Anwar

Supriyanto

Shirkah Journal of Economics and Business is a peer-reviewed journal published three times a year (January-April, May-August and September-December) by Faculty of Islamic Economics and Business, Institut Agama Islam Negeri (IAIN/ State Institute for Islamic Studies) Surakarta Central Java, Indonesia. The main objective of Shirkah is to offer an academic space of exchange ideas and initiate the increase number of qualified article produced by postgraduate students, practitioners and academicians.

\section{Editorial Office}

Ruang Jurnal Shirkah

Ground Floor, West Gate,

Faculty of Islamic Economics and Business

IAIN Surakarta

Jln. Pandawa No. 1, Kartasura, Sukoharjo, Jawa Tengah Kode Pos. 57168

Phone (+62271) 781516 Fax: (+62271)782336

E-mail: shirkahiainsurakarta@gmail.com

Website: http://shirkah.or.id/ 



\section{Shirkah}

Journal of Economics and Business

Vol. 2, No. 1, January-April 2017

ISSN: 2503-4235 (p); 2503-4243 (e)

\section{Table of Contents}

\section{Articles}

Ana Zahrotun Nihayah

Savings and Loans Program, The Revenue of Small Micro Entreprises and Poverty Reduction among Women Groups

Ana Fadhilah

Muslimah Entrepreneurship and Economic Empowerment in Pengajian

Umiyati

Local Economics Empowerment and Sharia Microfinance in Rural

Community Perception

Lathif Hanarif Rifqi

Community Empowerment through Islamic Microfinances Perceptions in Comparison

Ahmad Lukman Nugraha

Islamic Business Ethics and Islamic Microfinance in Pesantren Gontor

Nova Ch. Mamuaya

Service Quality and Non-Muslim Satisfaction Using Sharia Bank Products and Services 



\title{
Muslimah Entrepreneurship and Economic Empowerment in Pengajian
}

\author{
Ana Fadhilah \\ IAIN Metro Lampung \\ anadhila18@yahoo.com
}

\begin{abstract}
It is a requirement in the practice of economic enterprising to gain productive skill training and capitalization or provision of capital using the moving loan for the member. However, there is still constraint for this method, which is some members are being late to return the loan, because of some reasons. This paper aims to analyze the effect of the moving loan for the pengajian (religious gathering) of An Naml, especially who used it for the food processing business; and to analyze their income's allocation, whether the income is allocated for the consumption, education, and health or set the income aside for the religious fund, such as infaq, alms, kurban and hajj's fund. This paper employs qualitative and quantitative approaches, gathering data using in-depth interview, observation and distributing questioners to the 15 select members (purposive sampling). The analysis techniques used are descriptive analysis, paired t-test and correlation analysis. This paper found that the economic enterprise of the member of the An Naml religious gathering, according to the correlation test, proof that between the total income and the savings, before and after the loan given is positively related. In doing so, the connection between the total income and the religious fund before the loan given is related positively, but after the loan given the relation is undetected.
\end{abstract}

Keywords: entrepreneurship, pengajian, economic empowerment

\section{Introduction}

Suwarno (2007: 82-85) explains that the women in beach area district Temon, Kulon Progo actually have a great chances to increase their family's income. The Kulon Progo local government forming the moving loan fund called Usaha Ekonomi Desa Simpan Pinjam (Savings and Loan 
Village Enterprise), which is including the sea food processing training. Nevertheless, still this training program does not seem adequate to fulfill the society needs and also did not shown its effects, because the program is not sustained; the society still unable to getting the adequate knowledge about selling their product.

Most of the women, especially the women entrepreneur, always have the double roles, which are: job and family. In her research, Sari (2012: 25-35) did interviewing four success women entrepreneurs in Yogyakarta, and revealed that those women have to balancing their role in home and in their job. Their strategies to make their life balance are: personal management (self control), interpersonal familial management like time management, adjusting time with their family and their job, and the last is sharing their roles with the employer and adjusting their behavior with religion as life guidance.

Outside Indonesia, such as in Union of Emirat Arab (UEA), they try to decrease the amount of the foreign labor by improving the quality of their own labor, including female labor. In order to activate the female labor in the business field, the government established Female Entrepreneur Association. Intan (2011) does research on the motivation behind the UEA's female entrepreneur. After interviewing 16 female entrepreneurs, Intani explains that those women wanted to be an entrepreneur, because they really wanted to be independent and actualize themselves. They don't seem to have got a conflict with their family, their jobs and their social life, most of it happens because they really depend on their household's assistance. But, actually, in the beginning of their career, they have got so many obstacles, such as: the local culture which forbids women to work outside their home, and the lack of family and government support, and the most important is their own lack of business or managerial knowledge. 
Poverty happens not only in rural area, but takes place also in the city. Poverty is caused by the physical development in the city which needs vast area (Sulistiyani, 2004: 19). One of the biggest cities in Indonesia with a great development is Yogyakarta. The population in Yogyakarta in 2010 is 388.627 people; consisting of 189.137 males, and 199.490 females. There are not many households in Yogyakarta, but still, the new arrivals should be controlling to anticipate the uncontrollable of population growth. The District Umbulharjo is the district with the highest population in Yogyakarta according to the census done in 2010, with the 76.740 populations, consisting of 37.114 males and 39.626 females. The high population in this district has caused the high amount of poor people, which are 3.382 poor people in 2009 (BPS Kota Yogyakarta, 2012: 24).

The poverty raising process needs an enterprise intervention (Mariyanti, 2016). The society enterprise is a demand in development process. The enterprise in the society context is the individual ability to mix with other person to develop the usefulness of the society (Anwar, 2007: $3)$. The society enterprise is not only for the male population, because the society believed that females population also have a great involvement in development (Sakai, 2016). This fact is supporting by the amount of female population in Yogyakarta, especially in Umbulharjo, which is bigger than the male population.

Most of Indonesian females are Muslimah who able to imitate Khadijah, the prophet Muhammad's wife, whom is able to combine the woman's role as a wife, an entrepreneur and a house wives together. Meanwhile, it is presumable that the desire of practicing to enterprise and to improve the Indonesian woman, originated from Raden Adjeng Kartini. The female enterprise is not only the government responsibility, but also the society responsibility, and all the people should work together to make it happen. Allah said in the Quran, which explains that, all the people should be responsible to raising poverty: 
Every soul will be (held) in pledge for its deeds (38), Except the Companions of The Right Hand (39), (They will be) in Gardens (of delight); they will question each other (40), And (ask) the Sinners (41), What led you into Hell-Fire (42), They will say "We were not of those who prayed" (43), "Nor were we of those who fed the indigent" (44) (QS. al-Muddatstsir, 74: 38-44)

Shihab (2007: 379) explains that "giving food" supposed to be understood not mainly as giving the food literally but also has another meaning as giving help to others. It is also understood as a human position which is bound by the brotherhood, so we have to help to each other (Reisman, 2017). As the utterance of prophet Muhammad, "All mukmin is as a person, if he hurts his head, so his whole body is also hurt, he will have fever and unable to sleep at night (Hadith transmitted by Muslim).

Pengajian An-Naml is one of the religious gatherings which the member consists of ladies and female teenagers. Its head quarter is in Giwangan sub-district, Umbulharjo District Yogyakarta. This religious gathering had been established after the earthquake in Yogyakarta in 2006 by Mrs. Purbudi Wahyuni, the lecturer in Human Resource Management in UPN Veteran Yogyakarta, who also becomes the chief of the Social Managing Unit (UPS) in PNPM Mandiri Perkotaan in sub district Giwangan since 2009. In the beginning, this gathering is done in order to do the self-reflection and self-introspection after the Yogyakarta's earthquake, but then, this gathering done every Sunday afternoon until now.

In general, there are two advantages from the an- $\mathrm{Naml}$ religious gathering, those are: able to extend the member's view about religion and other life aspects, and facilitating the member to get many accesses needed by the member and also for the inhabitants around them. Through this gathering, there are three basic enterprising components, namely 
education, mental attitude and economic matters. This research mainly focuses on economics, especially economic matters with relation to the gathering members.

From the explanation, the purposes of this research are first, analyze the economic enterprise's target, especially which relating to the gathering member's business. Second, to analyze the effect of the moving loan for the an-Naml religious gathering, especially who used it for the food processing business, and to analyze their income's allocation, whether the income is allocated for the consumption, education, and health or set the income aside for the religious fund, such as infaq, alms, qurban and hajj's fund? Third, to analyze the theory and the practice of the Islamic sharia in muamalah system done by the an- $\mathrm{Naml}$ religious gathering, especially which is relating food processing business and the moving loan system.

The main data resources obtained from the gathering members' remarks and acts, gathered by active observation, deep interview and questioner's distribution to the selected members. The deep interview was conducted to the An Naml religious gathering founder to know about the foundation's programs, especially the enterprise program and economic program. Furthermore, the interview was conducted with the foundation's father to know about the moving loan system.

The secondary data obtained from the religious gathering's documents: attendance list, treasurer notes, and electronic media's note such as: the official blog from the gathering's leader describing the anNaml religious gathering's program and from the books which supported this research. In general, the populations used in this research are the house wives who have ever had the loan from this gathering, whether the house wives are the member of the gathering or not, whether the loan funds would be use to do business or not. The total population is 38 house 
wives $^{1}$. But, because there are a lot of business done by the loaner, and the business are also considered, thus, the respondents' choosing done by the purposive sampling technique, which the sample is taken with some considerations (Soeratno and Arsyad, 2008: 112). The considerations taken in this research are: a) the loaner must be a member of an-Naml religious gathering, b) the loaner mentioned in point a must have ever got the loan from this gathering, c) the member mentioned in point a should has got a food (and beverages also allowed) processing and still active doing the business, $d$ ) and willing to be the respondent.

The conditions above show there are obtained 15 members as samples in this research. The respondents' business is being observed, before and after the moving loan given by the gathering. However, to add and compare the information obtained, the researcher also interviewed the other 15 members gathering who also got the processing business, yet didn't get the loan, in order to know why they didn't get the loan or to know their respond about the gathering's programs.

In order to get the goal settled for this research, the researcher using some analysis tools. The quantitative descriptive analysis was conducted by presenting data in a table which able to represents all the samples taken. In this research the table is presenting: member's income table, fund allocation, percentage, mean value, modus value and median value. Quantitative descriptive translated into words taken from the observation and information from the members or the member's opinion which then being analyzed with their behavior, those words being reduced, triangulated, summarized and verified (Usman, et al., 2011: 130).

\footnotetext{
${ }^{1}$ Note : from the early periode $(2009$ - 2010) until the research done (periode 2012 - 2013), the moving loan from this foundation has done 68 times to 38 members. And for those periode, the members who borrowed twice or more only 21 members, and the members who borrowed the most are the food processing business person.
} 
This research also employs t-paired test to determine whether there is a difference on the members' income or not and the fund allocation every month before and after loan is given. There two ways to make the summary or the decision in this test, those are:

a) Comparing the value of $t$ count with $t$ table

- $-\mathrm{t}_{\text {table }} \leq \mathrm{t}_{\text {count }} \leq \mathrm{t}_{\text {table }}=\mathrm{H}_{0}$ rejected

- $\mathrm{t}_{\text {count }}<-\mathrm{t}_{\text {table }}$ or $\mathrm{t}_{\text {count }}>\mathrm{t}_{\text {table }}=\mathrm{H}_{0}$ accepted

b) Comparing significance or probability value $(\mathrm{P})$

$P$ value (sig 2 tailed value (significant) and $\alpha$ value $(0,05)$

- If $\mathrm{P}$ value $<\alpha$ value $\mathrm{H}_{0}$ rejected

- If $\mathrm{P}$ value $>\alpha$ value $\mathrm{H}_{0}$ accepted

$\alpha$ value is 5 percent or 0,05 , because the interval confidence is almost 95 percent. The method to determine the rejected area and accepted area are: $\alpha=5 \% \rightarrow$ because this is 2 sides test to find $t_{\text {table, }}$, so the $\alpha$ has to divided by $2, \rightarrow 5 \% / 2=2,5 \%$ or 0,025 .

- $\mathrm{df}=(\mathrm{N}-1) \rightarrow(15-1=14)$

- $\mathrm{t}_{\text {table }}(0,025: 14)=2,145$

The hypothesis formulations are:

$\mathrm{H}_{0}: \mu 1=\mu 2$ (proof that the average of parameter is similar with some other averages).

Ha: $\mu 1 \neq \mu 2$ (proof that the average of parameter is not similar with some other averages).

Correlation test was used to determine the closeness between two variables or more, which the data are quantitative and qualitative, so it is able to be called non parametric statistic. Correlation test in this research is a simple correlation test with two variables. The hypothesis formulations are:

$\mathrm{H}_{0}=$ there is no relation between variable 1 and variable 2.

$\mathrm{Ha}=$ there is a relation between variable 1 and variable 2 . 
Significance value used to determine to measure the relation's strength betweens variables. The value of correlation coefficient is between -1 and +1 , with the positive and negative nature.

- Positive correlation $(+) \rightarrow$ one direction means the change of one variable followed by the change of other variable to the same direction.

- Negative correlation $(-) \rightarrow$ contrary direction, means the change of one variable followed by the change of other variable to the different direction.

\section{Women and Society Enterprising}

Sulistiyani (2004; 79) defines enterprising as an effort to build the power by giving a push, motivation and to resurrect the awareness of the society's potential ability and how to improve it. Suharto (2010: 59) said that enterprises are process and goal. From the process, enterprise means activities to activate the power or to strengthen the weaker group. Meanwhile, in the goal, enterprise means the goal that has to be reached in the social change including: the powerful society, having the power, ability and knowledge to fulfill their whole life aspects.

Some literatures said that the enterprise concept were born since the industrial revolution and created after the modern Europe was born in the 18th century or the renaissance era (Hutomo, 2000: 1). Islam itself has introduced the concept of enterprise long before the renaissance era. In Islam, enterprise means how human act to survive its life in the world (Hadi, 2015). The verse bellow explains why a man should enterprise himself or changes him to survive in the world, and then Allah will help him to survive in the world.

Because Allah will never change the Grace which $\mathrm{He}$ hath bestowed on a people until they change what is in their (own) soul; and verify Allah is He who heareth and knoweth (all things) (QS.al-Anfal, 8: 53) 
Women have the right to worship or to do ibadah and struggle for their life same as the men. The size of the struggle depends on the closeness to Allah. Women should fight their right to do the worship, though their husband forbid them to do that, because awareness or hidayah is privately and independently give by Allah (Mutahhari, 1986: 95). Allah said in holy Quran:

Whoever works righteousness, man or woman, and has Faith, verily, We will give a new life, a life that is good and pure, and We will bestow on such their reward according to their actions (QS. An-Nahl, 16: 97).

The biggest and the greatest good deeds done by a woman is her role as a mother. Inside the household, man may be more dominant than a woman, but in children's growth perspective, a mother is irreplaceable. Even there is such a famous idiom, that is: mother is the first school for their children. To do her most important role as a mother, a woman should have an adequate knowledge, especially a religion knowledge, that is for her own goodness, for the children's growth, and also to strengthen her status as a worshipper to Allah whom says in the Qur'an:

... Allah will rise up to (suitable) ranks (and degrees), those of you who believe and who have been granted (mystic) knowledge. And Allah is well acquainted with all ye do (QS. Al Mujadilah, 58: 11)

The secular economic experts said that there are four production factors, those are: land, capital, work and some said system is also the production factor, but there are only two production factors, those are: land and work (Qardhawi, 1997: 144-146). Basically, capital and system are the part of work. Al-Koran commands the Moslems to always make an effort and forbid them to beg for others help all the time or make an effort which will make others suffer. 
Wife's main obligation is to take care of her family, but if her husband unable to fulfill all the family needs economically, she allowed to help her husband based on the mutual assistance foundation exactly suitable with Islam (Sakai, 2010). However, before the woman work outside the house, the main condition is the permission from her husband. It isn't so appropriate for a widow to depend on other people, besides working will help them worship Allah easier.

Islam has guaranteed a woman to work outside her home as long as it is suitable with the Islamic and sharia laws. A woman permitted to work outside her home as long as they maintain her behavior and fulfill her obligation as a wife and a mother (Syahatah, 1998: 64). About the ownership of her income,

And in no wise covet those things in which Allah hath bestowed His Gifts more freely on some of you than others; to man is allotted what they earn, and to women what they earn; but ask Allah of His bounty. For Allah hath full knowledge of all things (QS. An-Nisa, 4: 32)

"The hand above (giver) is better than the hand bellow (beggar)" (Hadith transmitted by Muttafaq 'Alaih)

If a woman has already had prosperous life and well educated, she should work for her surround and society need. Aisyah said:

Prophet Muhammad said, "Jibril always reminds me to do the good deeds to my neighbor, so I think I would have my neighbor's inheritance" (Hadith transmitted by Bukhari and Muslim).

\section{Religious Gathering Economic Enterprise}

Human being is created in different class; there is an upper class and lower class. In fact, poor or rich people are sunnatullah, or Allah decision and both are examination for human being. In reality, the people's 
ability to respond their social condition is varying. The middle - upper class, which has a higher education, has bigger chances to have a better job than the lower class, besides that, the upper class uses to have more money to make some business.

The economic enterprise program done by productive skill training together with aid from the PNPM Mandiri Perkotaan which gave the business tool and composing the business group under the supervising of the society enterprising program (BKM) called Giwangan Makmur that would be formed into cooperative (economic enterprise). The business group which consists of the gathering's member would have the fund for their capital from Trade and Industry Department, and then the fund is being improved with the moving loan system. Related with the aid given, such as: moving loan, training and tools, some members complain about: a) the aid isn't given to all the members, b) there is limitation on the aid giving, such as the aid only given to the member who lives in Giwangan, whereas there are some members from the outside Giwangan and, c) there is lack of compactness between the members, for the example some tools are always used by the chief only.

There is a major problem on moving loan program, that is the delay of the loan payment, most of it because of the fund is being lent by a member who doesn't have any business, the fund lent is not appropriate with the production needs, there is no controlling when the member using the loan fund and there is no accompany program on production process, most of members do not have the routine savings and some of the members confess that they don't have any money to pay the loan, whereas they do the production process everyday. Meanwhile, the reason why 15 other member don't get the loan are, the 10 members don't want the loan and they seldom attend the gathering, 3 members confess they only wanted gift and not loan, and the 2 members don't get the loan, because they don't live in Giwangan. 
The descriptive analysis result shows the average income before and after the loan given, whether the members having the food processing business or having another business, is increasing. Especially on the food processing business, the income increase $2.16 \%$. However, if we take a deeper experiment, there are only 5 people (about 33.3\%) has the income's increase, and 4 people $(26.7 \%)$ the income isn't affected by the loan and 6 people $(40 \%)$ the income was decreasing.

The result from the descriptive analysis according to monthly income (especially for consumption, education and health fee) compare with the proportion of the total income before and after getting the loan, it is known that the education fee is decreasing $23.2 \%$ after the member is given the loan, before the loan given the education fee is $0.14 \%$. One of the causes is the member sending their children to the higher education level. From the separate fund, found that that the separate fund used for saving increasing $19.1 \%$, the fund used for alms and other religious fund is also increasing $19.9 \%$. From the income's proportion, it is proof that the increasing fund is only happen for the saving fund, which is increasing from 0.12 becomes 0.14 , whereas the religious fund is stagnant or stable $(0,08)$. Ironically, the increasing of the saving fund happens because there is an increasing $40.4 \%$ in the household loan. The paired t-test analysis result shown the absolute or proportion value from the total income before and after the loan given in the table below:

Table 1

Paired sample t-test

\begin{tabular}{|c|c|c|c|c|}
\hline $\begin{array}{c}\text { The two } \\
\text { different } \\
\text { averages test }\end{array}$ & t table & $t$ count & Sig (2-tailed) & Note \\
\hline Total Income & 2,145 & $-2,403$ & 0,031 & $\begin{array}{c}\mathrm{H}_{0} \text { rejected (there is } \\
\text { difference) }\end{array}$ \\
\hline $\begin{array}{l}\text { Food Business } \\
\text { Income }\end{array}$ & 2,145 & $-0,142$ & 0,889 & $\begin{array}{c}\mathrm{H}_{0} \text { accepted (there is no } \\
\text { difference) }\end{array}$ \\
\hline $\begin{array}{l}\text { Consumption } \\
\text { Allocation }\end{array}$ & 2,145 & $-3,401$ & 0,004 & $\begin{array}{c}\mathrm{H}_{0} \text { rejected (there is } \\
\text { difference) }\end{array}$ \\
\hline
\end{tabular}




\begin{tabular}{|c|c|c|c|c|}
\hline $\begin{array}{c}\text { Education } \\
\text { Allocation }\end{array}$ & 2,145 & 0,870 & 0,399 & $\begin{array}{c}\mathrm{H}_{0} \text { accepted (there is no } \\
\text { difference) }\end{array}$ \\
\hline $\begin{array}{c}\text { Health } \\
\text { Education }\end{array}$ & 2,145 & $-1,293$ & 0,217 & $\begin{array}{c}\mathrm{H}_{0} \text { accepted (there is no } \\
\text { difference) }\end{array}$ \\
\hline $\begin{array}{c}\text { Savings } \\
\text { allocation }\end{array}$ & 2,145 & $-0,926$ & 0,370 & $\begin{array}{c}\mathrm{H}_{0} \text { accepted (there is no } \\
\text { difference) }\end{array}$ \\
\hline $\begin{array}{c}\text { Religious } \\
\text { Fund } \\
\text { Allocation }\end{array}$ & 2,145 & $-1,925$ & 0,075 & $\mathrm{H}_{0}$ accepted (there is no \\
difference)
\end{tabular}

Source: Primary data (processed)

Table 2

Paired sample t-test

\begin{tabular}{|c|c|c|c|c|}
\hline $\begin{array}{c}\text { The two different } \\
\text { averages test }\end{array}$ & t table & t count & $\begin{array}{c}\text { Sig } \\
\text { (2-tailed) }\end{array}$ & Note \\
\hline Total Income & 2,145 & 2,154 & 0,049 & $\begin{array}{c}\mathrm{H}_{0} \text { rejected (there is } \\
\text { difference) }\end{array}$ \\
\hline $\begin{array}{c}\text { Food Business } \\
\text { Income }\end{array}$ & 2,145 & $-0,628$ & 0,540 & $\begin{array}{c}\mathrm{H}_{0} \text { accepted (there is no } \\
\text { difference) }\end{array}$ \\
\hline $\begin{array}{c}\text { Consumption } \\
\text { Allocation }\end{array}$ & 2,145 & 1,680 & 0,115 & $\begin{array}{c}\mathrm{H}_{0} \text { accepted (there is no } \\
\text { difference) }\end{array}$ \\
\hline $\begin{array}{c}\text { Education } \\
\text { Allocation }\end{array}$ & 2,145 & $-1,085$ & 0,296 & $\begin{array}{c}\mathrm{H}_{0} \text { accepted (there is no } \\
\text { difference) }\end{array}$ \\
\hline $\begin{array}{c}\text { Health Education } \\
\text { Savings allocation }\end{array}$ & 2,145 & $-0,495$ & 0,628 & $\begin{array}{c}\mathrm{H}_{0} \text { accepted (there is no } \\
\text { difference) }\end{array}$ \\
\hline $\begin{array}{c}\text { Religious Fund } \\
\text { Allocation }\end{array}$ & 2,145 & 1,382 & 0,189 & $\begin{array}{c}\mathrm{H}_{0} \text { accepted (there is no } \\
\text { difference) }\end{array}$ \\
\hline Infaq's allocation & 2,145 & 0,823 & 0,424 & $\begin{array}{c}\mathrm{H}_{0} \text { accepted (there is no } \\
\text { difference) }\end{array}$ \\
\hline Alm allocation & 2,145 & $-1,824$ & 0,090 & $\begin{array}{c}\mathrm{H}_{0} \text { accepted (there is no } \\
\text { difference) }\end{array}$ \\
\hline
\end{tabular}

Source: Primary data (processed)

Correlation test between the total income with the savings and religious funds, before and after the moving loan given explains in the table below:

Vol. 2 No. 1, January - April 2017 


\section{Table 3}

Correlation Test

\begin{tabular}{|c|c|c|c|}
\hline Correlation & $\begin{array}{c}\text { Pearson } \\
\text { Correlation } \\
\text { on }\end{array}$ & $\begin{array}{c}\text { Sig. } \\
\text { (2-tailed) }\end{array}$ & Note \\
\hline $\begin{array}{c}\text { Total income before the loan - } \\
\text { savings before the loan }\end{array}$ & $\mathbf{0 , 8 9 6}$ & $\mathbf{0 , 0 0 0}$ & $\begin{array}{c}\text { Correlated } \\
\text { positively }\end{array}$ \\
\hline $\begin{array}{c}\text { Total income after the loan - } \\
\text { the savings after the loan given }\end{array}$ & $\mathbf{0 , 8 6 0}$ & $\mathbf{0 , 0 0 0}$ & $\begin{array}{c}\text { Correlated } \\
\text { positively }\end{array}$ \\
\hline $\begin{array}{c}\text { Total income before the loan - } \\
\text { religious fund before the loan }\end{array}$ & $\mathbf{0 , 5 4 9}$ & $\mathbf{0 , 0 3 4}$ & $\begin{array}{c}\text { Correlated } \\
\text { positively }\end{array}$ \\
\hline $\begin{array}{c}\text { Total income after the loan - } \\
\text { the religious fund after the loan } \\
\text { given }\end{array}$ & $\mathbf{0 , 1 8 8}$ & $\mathbf{0 , 5 0 3}$ & $\begin{array}{c}\text { No correlation } \\
\text { there is only } \\
\text { slightly correlation, } \\
\text { so being neglected) }\end{array}$ \\
\hline
\end{tabular}

Source: Primary data (processed)

\section{Food Processing Indicators in Islamic Perspective}

Muslim has to think carefully about food they eat, we have to be selective in choosing our food. Food we are consumed should be good (thoyyib), clean and halal (lawful), as Allah said the Qur'an, "O ye people, Eat what is on earth, lawful and good and do not follow the footsteps of the evil one, for he is to you an avowed enemy" (QS. al-Baqarah, 2: 168).

The goodness and the lawful of the food, not only from the substances of the food, but also the way we get the food, the capital we have to buy the food, the cooking process and also its sales process. The goodness of the food is also seen from the nutrition quality, its cleanliness, its hygiene, so the food able to make the human's body healthy. Prophet Muhammad said, "The body has the rights of you." The hadith means that human being have an obligation to take care of their healthiness, so their body able to function normally.

According to the food processing indicators, there are some members who does not really care about the cleanliness and healthiness 
when processing the food. Meanwhile from the moving loan agreement, the an-Naml religious gathering still using the interest system on the moving loan, which is the loaner have to pay the extra $10 \%$ from the main loan fund, for 11 months. However, some keep saying, that the $10 \%$ extra payment is a business share from the loaner or the alms from the loaners, which will come back to them again.

\section{Conclusion}

The economic enterprise of the member of the an-Naml religious gathering was conducted by business training, the tool giving and moving loan to the business owner. The condition of their business after the loan is given is seen in 5 people's income is increasing (33,3\%), 4 other people $(26,7 \%)$ have the undisturbed income (neither increase nor decrease) and 6 other people (40\%) the income is decrease. The income allocation for consumption and health fee is increasing, but the income for the education fee is decreasing. The reality happens because they unable to afford their children to the higher education level. The separate income is used for savings and the religious fund is increasing, but ironically their loan is also increasing.

Paired sample t-test proof that there a difference between the total income before the loan given and the total income after the loan given. However, if we see it from the food processing business income (absolute value and proportion value), there is a difference on the proportion value, which the value of the $t$ count $>t$ table $(2,154>2,145)$. From the income's allocation the difference is undetected, except on the absolute value on the consumption fee which the value is: $-3,401<-2,145$. From the separate fund, whether the fund is used for the saving or for the religious fund, there is no detail difference except for the infaq and alm's fund. According to the correlation test proof that between the total income and the savings, before 
and after the loan given is positively related. In doing so, the connection between the total income and the religious fund before the loan given is related positively, but after the loan given the relation is undetected with the significance value $(0,503>0,05)$.

According to the food processing indicator, there are still many members who do not care about the cleanliness and the healthiness of the cooking process. The an-Naml gathering still using the interest program, or known as riba, because still oblige the loaner to pay extra $10 \%$ from their main loan. In order to extinguish the social imbalance between gathering member, the management should consider about giving the loan to all gathering's member, because most of the gathering's member coming from outside Giwangan. Instead giving the loan, the management should control the loan usage by the loaner and accompanying the production process. Therefore the management able to know their improvement and knowing their obstacles and helping them find the answers. After knowing that their loan is increasing, the member hope the management to ensure and inspire the member to pay their loan and to make more savings, so the members no longer depend on the loan or installment anymore.

Because this gathering based on the Islam law, this foundation should materialize the Islamic law on doing their activities, such as do not do the riba or interest on their loan, so indirectly, the member also got the Islamic education about riba or interest and able to do the right muamalah system. Meanwhile, about the business improvement, Islam offers the better and halal business system and to make a profit on both side, the management and the member, as long as practiced according to the Islamic rules, that is the akad or agreement is correct about the musharaka or mudharaba.

It would be the best if the gathering's management improve the content of their gathering, such as bringing the orator expertise guest 
lecture, so she or he not only talk about ibadah but also about business ethic and the most important she or he could explain about installment system and riba or interest. This is would be able to be socialization about the importance to know about the Islamic economy to the member, because likes it or not, who does the muamalah or business everyday is housewives and business owner.

\section{References}

Al-Ied, I. D. (2001) Syarah Hadits Arba'in Imam Nawawi terj. Muhammad Thalib, Yogyakarta: Media Hidayah.

Al-Jamal, I. M. (1994). Fiqhul Mar'atil Muslimah terj. Zaid Husein Alhamid. Jakarta: Pustaka Amani.

Al-Mishri, R.Y. (1991) Al-Jami' fi Ushul Arriba. Damaskus: Darul Qalam. Al-Koran digital yang telah diverifikasi dengan aslinya.

Anwar. (2007) Manajemen Pemberdayaan Perempuan (Perubahan Sosial Melalui Pembelajaran Vocational Skills pada Keluarga Nelayan). Bandung: Alfabeta.

Baqi, M. F.A. (1996), Al-Lu'lu wa Marjan (Himpunan hadits shahih disepakati oleh Bukhari dan Muslim) terj. Salim Bahreisy. Surabaya: Bina Ilmu.

Djakfar, M. (2007). Agama, Etika dan Ekonomi Wacana Pengembangan Ekonomi Rabbaniyah. Malang: UIN Malang Press.

Hadi, R., Wahyudin, U., Ardiwinata, J.S., Abdu, W.J. (2015). Education and Microfinance: an Alternative Approach to the Empowerment of the Poor People in Indonesia. SpringerPlus 4 (1), 244.

Hartono. (2008). SPSS 16,0 Analisis Data Statistika dan Penelitian. Yogyakarta: Pustaka Pelajar. 
Hutomo, M. Y. (2000). Pemberdayaan Masyarakat (Seminar Sehari diselenggarakan Bappenas), Jakarta: Artikel PDF Bappenas.

Itani, H. Dkk. (2011) "United Arab Emirates Female Entrepreneurs: Motivation and Frustationd", International Journal of Human Resource Management, Emerald Group Publishing Limited, Vol. 30.

Kelompok Kerja Sanitasi Kota Yogyakarta (2012) Gambaran Umur Kota Yogyakarta, PDF ppsp.nawasis.info/...yogyakarta/BAB2 BPS\%20 YK.p.

Majma' F. I. (2005) Qurarat wa Tausiyat Ad-Daurah As-Sadisata Asyrah Limajlis Al-Majma' Al-Fiqh Al-Islamiy", Dubai (UEA): PDF.

Mariyanti, T., Mahfudz, A.A. (2016). Dynamic Circular Causation Model in Poverty Alleviation: Empirical Evidence from Indonesia. Humanomics 32 (3), pp. 275-299.

Mudhafier, F. dkk. (2004). Makanan Halal Kebutuhan Umat dan Kepentingan Pengusaha, Jakarta: Zakia Press.

Mutahhari, M. (1986). Wanita dan Hak-Haknya dalam Islam terj. dari The Right of Women in Islam, Bandung: Penerbit Pustaka.

Qardhawi, Y., (1995). Kiat Islam Mengentaskan Kemiskinan, Jakarta: Gema Insani Press.

Qardhawi, Y., 1997, Peran Nilai dan Moral dalam Perekonomian Islam terj. dari "Daurul Qiyam wal akhlaq fil Iqtishadil Islami”. Jakarta: Rabbani Press.

Rahman, A. (1996). Doktrin Ekonomi Islam (Economic Doctrines of Islam). terj. Soeroyo dan Nastanging, Yogyakarta: Dana Bhakti wakaf.

Reisman, E. (2017). Troubling Tradition, Community, and Self-Reliance: Reframing Expectations for Village Seed Banks. World Development 98, pp. 160-168.

Sakai, M. (2010). Growing Together in Partnership: Women's Views of the Business Practices of an Islamic Savings and Credit Cooperative (Baitul Maal wa Tamwil) in Central Java Indonesia. Women's Studies 
International Forum 33 (4), pp. 412-248.

Sakai, M., Fauzia, A. (2016). Performing Muslim Womanhood: Muslim Business Women Moderating Islamic Practices in Contemporary Indonesia. Islam and Christian-Muslim Relations 27 (3), pp. 229-249. Shihab, M. Q. (2007). Membumikan Al-Koran Fungsi dan Peran Wahyu dalam Kehidupan Masyarakat, Bandung: Mizan Media Utama.

Soeratno dan Arsyad, L. (2008). Metodologi Penelitian untuk Ekonomi dan Bisnis. Yogyakarta: UPP STIM YKPN.

Sulistia, Anjar. (2008). SPSS for Windows, Yogyakarta: UPT Laboratorium STIKESS Surya Global.

Sulistiyani, A. T. (2004), Kemitraan dan Model-Model Pemberdayaan. Yogyakarta: Gava Media.

Suwarno, B. (2007). Perempuan dan Program Penaggulangan Kemiskinan (Program Penanggulangan Kemiskinan di Kecamatan Temon, Kulonprogo DI Yogyakarta), Yogyakarta: Tesis UGM.

Syahatah, H. (1998). Ekonomi Rumah Tangga Muslim terj. dari Iqtihsad AlBaitilmuslim fi Dau'isy Syariatil-Islamiyah, Jakarta: Gema Insani Press.

Sari, V. D. (2012) Strategi Menyeimbangkan Peran Kerja dan Keluarga: Studi Fenomenologi pada Perempuan Wirausaha. Yogyakarta: Tesis UGM.

Usman, dkk. (2009) Metodologi Penelitian Sosial, Jakarta: Bumi Aksara. 


\section{Shirkah Author Guidelines}

Shirkah currently offers two routes to submit manuscripts. We highly recommend to submit the articles which are made using OJS (Open Journal System). Feel free register as author soon through visiting http:// shirkah.or.id/index.php/home/user/register. The authors may directly send their manuscripts, along with their resume, to shirkahiainsurakarta@ gmail.com. Please prepare your manuscripts, using following guidelines:

1. Manuscript must be written in English. Submitted articles should not have been published or be under review for publication with another journal.

2. Manuscript's length is about $15-20$ pages, typed in one-half spaced on A4-paper size.

3. Manuscript must include an $150-200$ word abstract and keywords.

4. Manuscript must be arranged as follows: Title, Name of Author, E-mail address, Abstract, Keywords, Introduction (including method if any), Discussion, Conclusion, References.

5. Manuscript's titles not more than ten words.

6. Manuscript must be submitted in Microsoft Word or RTF.

7. Arabic words should be transliterated according to the style of International Journal of Middle Eastern Studies.

8. Manuscript references are preferably derived from the up-to-date references.

9. The author's resume should be submitted separately, consisting of at least full name, institutional address, phone number, areas of studies, and recent publications (if any).

10. Shirkab use APA Style 6th edition (2010) as reference format writing. We suggest the use of a reference manager software such as Mendeley, Zotero, and Endnote at templating the citation style. APA Style to be used is as follows: 


\section{Book with single author}

Swann, G. M. Peter. (2014). The Economics of Innovation an Introduction. Cheltenhum \& Northampton: Edward Elgar.

in-text citation: (Swann, 2014)

\section{Articles in reference books}

Alatas, S. F. (2006). Islam and the Science of Economics in Abu Rabi', I.M. The Blackwell Companion to Contemporary Islamic Thought. USA: Willey-Blackwell (pp. 587-606).

in text citation: (Alatas, 2006)

\section{E-Book}

Hackett, Rosalind (2007). "Religous Dimentions of War and Peace: Introduction.” Dalam Gerrie ter Haar dan Yoshio Tsuruoka (Ed.), Religion and Society: An Agenda for the 21st Century (h. 3-6). Retrieved from http:// brill.nl.

in text citation: (Hackett, 2006)

\section{Master's thesis, from a commercial database}

McNieI, D. S. (2006). Meaning through narrative: A personal narrative discussing growing up with an alcoholic mother (Master's thesis). Available from ProQuest Dissertations and Theses database. (UMI No. 1434728)

in text citation: (Mc Niel, 2006)

\section{Doctoral dissertation, from an institutional database}

Adams, R. J. (1973). Building a foundation for evaluation of instruction in higher education and continuing education (Doctoral dissertation). Retrieved from http://www.ohiolink.edu/etd/

in text citation: (Adams, 1973) 


\section{Doctoral dissertation, from the web}

Bruckman, A. (1997). MOOSE Crossing: Construction, community, and learning in a networked virtual world for kids (Doctoral dissertation, Massachusetts Institute of Technology). Retrieved from http:/www-static. cc.gatech.edu/--asb/thesis/ in text citation: (Bruckman, 1997)

\section{Journal article with No DOI}

Bourkhis, K., and Nabi, M. S. (2013). Islamic and conventional banks' soundness during the 2007-2008 financial crisis. Journal Metrics, 22(2), 68-77.

in-text citation: (Bourkhis \& Nabi, 2013).

\section{Journal article with DOI}

Ichwan, M. (2012). The Local Politics Of Orthodoxy: The Majelis Ulama Indonesia in the Post-New Order Banten. Journal Of Indonesian Islam, 6(1), 166-194. doi:http://dx.doi.org/10.15642/JIIS.2012.6.1.166-194

In text citation : (Ichwan, 2012)

\section{Abstract as citation}

Hasan, N. (2012). Islamist Party, Electoral Politics And Da'wah Mobilization Among Youth : The Prosperous Justice Party (PKS) in Indonesia. Journal of Indonesian Islam, 6(1), 17-47. Abstract from http:// jiis.uinsby.ac.id/index.php/jiis/article/view/97

in text citation : (Hasan, 2012)

\section{Mass media article}

Sahal, Akhmad (2014, March 2). Kiai Sahal dan Realisme Fikih.Tempo Magazine, p. 120.

in text citation : (Sahal, 2014) 


\section{Research report}

Fisher, B. S., Cullen, F. T., \& Turner, M. G. (2000). The Sexual Victimization of College Women. Research Report.

in text citation : (Fisher, Cullen, Turner, 2000)

\section{Monograph}

Routray, Bibhu Prasad (2013), National Security Decision-Making in India (RSIS Monograph No. 27). Singapura: Rajaratnam School of International Studies.

in text citation : (Routray, 2013)

\section{Proceeding article}

Sudibyakto, Hizbaron, D.R., \& Jati, R (Ed.) (2009), Proceeding International Seminar Disaster Theory, Research and Policy. International seminar held by Sekolah Pascasarjana, Universitas Gajahmada, Yogyakarta, 8-9 Desember 2009.

in text citation : (sudibyakto and Jati, 2009)

\section{Paper conference/seminar/symposium}

Janutama, Herman Sinung (2011). "Kraton dan Hubungan Antar Agama." Paper presented in Seminar Kraton dan Panatagama held by Center for the Study of Islam and Social Transformation (CISForm), Yogyakarta, 17 November.

in text citation :(Janutama, 2011)

\section{Online article in web}

Shiva, (2006, February). Bioethics: A Third World Issue. Native-web. Diperoleh dari http://www.nativeweb.org/ pages/legal/shiva.html

in text citation : (Shiva, 2006) 


\section{Online research report}

Kessy, S. S. A., \& Urio, F M. (2006). The contribution of microfinance institutions to poverty reduction in Tanzania (Research Report No. 06.3). Retrieved from Research on Poverty Alleviation website: http://www. repoa.or.tz /documents_storage/Publications/Reports/06.3_Kessy_and_ Urio.pcif

in text citation : (kessy and urion, 2006)

\section{Holy book}

Qur an, $2(25)$

In text citation : (Q. al-Baqarah 2:25).

\section{Encyclopaedia}

Graycar, Adam (1992). Social Welfare Policy. Dalam Mary Hawkesworth dan Maurice Kogan (Ed.), Encyclopedia of Government and Politics (Vol. 1). London: Routledge.

in text citation : (Graycar, 1992)

\section{Interview}

Sultan Hamengkubuwono X (interview, 2011, April 19)

in text citation: (Hamengkubuwono, 2011)

\section{Documentary film}

Steijlen, Fridus (2008). A Day in the Life of Indonesia [documentary film, 58 minutes]. Leiden: KITLV Press.

in text citation : (Steijlen, 2008) 
Vol. 2 No. 1, January - April 2017 